\title{
Role of Superoxide Anions in the Redox Changes Affecting the Physiologically Occurring $\mathrm{Cu}(\mathrm{I})$-Glutathione Complex
}

\author{
Hernán Speisky, ${ }^{1,2}$ Camilo López-Alarcón, ${ }^{3}$ Claudio Olea-Azar, ${ }^{2}$ \\ Cristian Sandoval-Acuña, ${ }^{1}$ and Margarita E. Aliaga ${ }^{3}$ \\ ${ }^{1}$ Nutrition and Food Technology Institute, University of Chile, Santiago 7830489, Chile \\ ${ }^{2}$ Faculty of Chemical and Pharmaceutical Sciences, University of Chile, Santiago 8380492, Chile \\ ${ }^{3}$ Facultad de Química, Pontificia Universidad Católica de Chile, Santiago 6094411, Chile
}

Correspondence should be addressed to Hernán Speisky, hspeisky@inta.uchile.cl

Received 7 June 2011; Accepted 15 July 2011

Academic Editor: Zhe-Sheng Chen

Copyright (c) 2011 Hernán Speisky et al. This is an open access article distributed under the Creative Commons Attribution License, which permits unrestricted use, distribution, and reproduction in any medium, provided the original work is properly cited.

\begin{abstract}
The physiologically occurring copper-glutathione complex, $\left[\mathrm{Cu}(\mathrm{I})-[\mathrm{GSH}]_{2}\right]$, has the ability to react continually with oxygen, generating superoxide anions $\left(\mathrm{O}_{2}{ }^{--}\right)$. We addressed here the effects that superoxide removal has on the redox state of $\mathrm{Cu}(\mathrm{I})$ and GSH present in such complex and assessed the formation of Cu(II)-GSSG as a final oxidation product. In addition, we investigated the potential of a source of $\mathrm{O}_{2}{ }^{\bullet-}$ external to the $\mathrm{Cu}(\mathrm{I})-[\mathrm{GSH}]_{2}$ complex to prevent its oxidation. Removal of $\mathrm{O}_{2}{ }^{{ }^{-}}$from a Cu(I)$[\mathrm{GSH}]_{2}$-containing solution, whether spontaneous or Tempol-induced, led to time-dependent losses in GSH that were greater than those affecting the metal. The losses in GSH were not accompanied by increments in GSSG but were largely accounted for by the cumulative formation of $\mathrm{Cu}(\mathrm{II})$-GSSG molecules. Notably, the redox changes in $\mathrm{Cu}(\mathrm{I})$ and GSH were totally prevented when $\mathrm{Cu}(\mathrm{I})-[\mathrm{GSH}]_{2}$ was coincubated with hypoxanthine/xanthine oxidase. Data suggest that the generation of $\mathrm{O}_{2}{ }^{{ }^{-}}$by $\mathrm{Cu}(\mathrm{I})-$ $[\mathrm{GSH}]_{2}$ implies the obliged formation of an intermediate whose subsequent oxidation into $\mathrm{Cu}(\mathrm{II})$-GSSG or back reduction into $\mathrm{Cu}(\mathrm{I})-[\mathrm{GSH}]_{2}$ is favoured by either the removal or the addition of $\mathrm{O}_{2}{ }^{\bullet-}$, respectively.
\end{abstract}

\section{Introduction}

The $\mathrm{Cu}(\mathrm{I})$-glutathione complex is believed to be formed within cells during the interaction between $\mathrm{Cu}^{2+}$ ions and reduced glutathione (GSH). In fact, following the exposure of either human hepatoma cells (HACs) $[1,2]$ or intestinal epithelial cells (Caco-2) [3] to copper, most of the metal is recovered bound to GSH molecules, forming, most likely, a $\mathrm{Cu}(\mathrm{I})-[\mathrm{GSH}]_{2}$ complex. The exact biological role of the latter complex has not been fully established. Some studies suggest, however, that it may play a role as carrier of $\mathrm{Cu}(\mathrm{I})$ to copperdependent enzymes, such as SOD [4], and to copper-storing and copper-transporting proteins, such as metallothionein $[5,6]$ and ceruloplasmin [7], respectively.

Studies conducted in noncellular systems indicate that mixing $\mathrm{Cu}^{2+}$ ions and GSH in a molar ratio equal to or greater than $1: 3$ leads to the swift formation of $\mathrm{Cu}(\mathrm{I})$ $[\mathrm{GSH}]_{2}[8-10]$, as in $(\mathrm{Rx} .1)$

$$
2 \mathrm{Cu}^{2+}+6 \mathrm{GSH} \longrightarrow 2 \mathrm{Cu}(\mathrm{I})-[\mathrm{GSH}]_{2}+\mathrm{GSSG}+2 \mathrm{H}^{+} \quad(\mathrm{Rx} .1)
$$

The formation of the $\mathrm{Cu}(\mathrm{I})$-glutathione complex has been supported by ${ }^{1} \mathrm{H}-\mathrm{NMR}$ and EPR studies $[4,11]$ and would involve an initial stoichiometric reduction of $\mathrm{Cu}^{2+}$ by $\mathrm{GSH}$ and a subsequent chelation of the cuprous ion by two additional GSH molecules [10]. Binding of GSH has been suggested to stabilize $\mathrm{Cu}(\mathrm{I})$ in a form that, for long time, was presumed to be redox-inactive due to the relative stability that the complex exhibits in oxygen-containing solutions $[4,12-14]$. Contending such concept, we recently provided evidence to support the contention that rather than redoxinactive, the $\mathrm{Cu}(\mathrm{I})-[\mathrm{GSH}]_{2}$ complex is able to react with 
molecular oxygen in a reaction which reversibly leads to the formation of superoxide radicals and an "intermediate oxidized complex" (IOC) $[15,16]$ (Rx. 2)

$$
\mathrm{Cu}(\mathrm{I})-[\mathrm{GSH}]_{2}+\mathrm{O}_{2} \rightleftarrows \mathrm{IOC}+\mathrm{O}_{2}^{\bullet-}
$$

An important "exception" to the reversibility of (Rx. 2) would be given by the presence of a superoxide-interceptor in the media. In fact, we recently described [16] that the addition of SOD to a solution containing $\mathrm{Cu}(\mathrm{I})-[\mathrm{GSH}]_{2}$ leads to the formation of a stable product whose NMR spectrum is identical to that of a preformed $\mathrm{Cu}(\mathrm{II})$-GSSG complex. Thus, removal of superoxide from ( $\mathrm{Rx} .2)$ appears to drive the oxidative conversion of IOC into $\mathrm{Cu}$ (II)-GSSG in a presumably irreversible manner. In the present study, we have addressed the redox changes that, under conditions leading to superoxide removal, affect the metal and the thiol present in the $\mathrm{Cu}(\mathrm{I})-[\mathrm{GSH}]_{2}$ complex during its oxidative conversion into $\mathrm{Cu}$ (II)-GSSG. In addition, we investigated the potential of a source of superoxide anions, external to $(\mathrm{Rx} .2)$, to prevent the oxidation of $\mathrm{Cu}(\mathrm{I})-[\mathrm{GSH}]_{2}$ into $\mathrm{Cu}(\mathrm{II})-\mathrm{GSSG}$.

\section{Experimental}

2.1. Chemicals and Reagents. Cupric chloride $\left(\mathrm{CuCI}_{2}\right.$. $\left.2 \mathrm{H}_{2} \mathrm{O}\right)$, reduced glutathione $(\mathrm{GSH})$, oxidized glutathione (GSSG), glutathione reductase (GR; E.C. 1.6.4.2. from baker's yeast), $\beta$-Nicotinamide adenine dinucleotide $2^{\prime}$ phosphate reduced tetrasodium salt hydrate (NADPH), hypoxanthine (HX), xanthine oxidase (XO; E.C. 1.17.3.2. from bovine milk), bathocuproine disulfonic acid (BCS), and 5-(3-carboxy-4-nitrophenyl)disulfanyl-2-nitrobenzoic acid (DTNB) were all purchased from Sigma-Aldrich. 4-hydroxy2,2,6,6,-tetramethylpiperidine-1-oxyl (Tempol) was purchased from Calbiochem. EDTA was from Bio-Rad Laboratories. All aqueous solutions were prepared in Chelex-100treated Tris-buffer (20 mM; pH 7.4).

2.2. Preparation of Copper-Glutathione Complexes. The $\mathrm{Cu}(\mathrm{I})-[\mathrm{GSH}]_{2}$ complex was prepared as previously reported [15], mixing $\mathrm{CuCI}_{2}$ and $\mathrm{GSH}$ in a $1: 3$ molar ratio. Whenever referring to a given concentration of such complex, it should be understood that it reflects the concentration of copper used in its preparation. The $\mathrm{Cu}(\mathrm{II})-\mathrm{GSSG}$ complex (there on preformed complex) was prepared by direct mixing of $\mathrm{CuCI}_{2}$ and GSSG in a 1:1 molar ratio as previously described [17]. Unless indicated otherwise, solutions containing the $\mathrm{Cu}(\mathrm{I})$ $[\mathrm{GSH}]_{2}$ and $\mathrm{Cu}(\mathrm{II})-\mathrm{GSSG}$ complexes were always prepared immediately (90 seconds) before using.

2.3. Determination of Thiol-Titratable Groups. Thiol-titratable groups (TTG) were quantified employing DTNB as thiol reacting agent $[18,19]$. The increase in $\mathrm{OD}_{412 \mathrm{~nm}}$ associated with the formation of $5^{\prime}$-thio-2-nitrobenzoic acid (TNB) was monitored at $30^{\circ} \mathrm{C}$ in a 96-well plate using a Multi-Mode Microplate Reader (Synergy HT), as done previously [20]. The assay was initiated by the addition of samples of the $\mathrm{Cu}(\mathrm{I})-[\mathrm{GSH}]_{2}$ complex (Tempol-treated and control) to a solution containing a mixture of DTNB $(24 \mu \mathrm{M})$ plus EDTA ( $2 \mathrm{mM})$. Results were estimated using a molar absorption coefficient of $14.15 \mathrm{mM}^{-1} \mathrm{~cm}^{-1}$ [21], and expressed as GSH equivalents. Control experiments were carried out using GSH instead of the complex.

2.4. Determination of the $\mathrm{Cu}(I I)-G S S G$ Complex. The concentration of $\mathrm{Cu}(\mathrm{II})-\mathrm{GSSG}$ in solutions containing a preformed complex was assessed as described by Postal et al. [17], measuring the optical density at $625 \mathrm{~nm}$ in a Unicam He $\lambda$ ios $\alpha$ spectrophotometer. Likewise, the formation of such complex within a solution containing a mixture of the $\mathrm{Cu}(\mathrm{I})$ $[\mathrm{GSH}]_{2}$ complex plus Tempol (incubated during 0-90 min) was also assessed at $625 \mathrm{~nm}$. Neither $\mathrm{Cu}^{2+}$ nor GSH, Cu(I)$[\mathrm{GSH}]_{2}$, or Tempol exhibited significant absorbance at such wavelength. Results were estimated using a molar absorption coefficient of $60 \mathrm{M}^{-1} \mathrm{~cm}^{-1}$ [17] and expressed as millimolar concentration of $\mathrm{Cu}(\mathrm{II})-\mathrm{GSSG}$.

2.5. Determination of EDTA-Releasable Oxidized Glutathione. $\mathrm{Cu}$ (II)-GSSG was assessed employing the NADPH/glutathione reductase assay, as described by Tietze [22] but in the presence of added EDTA $(2 \mathrm{mM})$. The decay in $\mathrm{OD}_{340 \mathrm{~nm}}$ associated with the formation of $\mathrm{NADP}^{+}$was monitored at $30^{\circ} \mathrm{C}$. The assay was initiated after the addition of NADPH, glutathione reductase and EDTA to a cuvette containing either a freshly prepared $\mathrm{Cu}(\mathrm{I})-[\mathrm{GSH}]_{2}$ complex, a $\mathrm{Cu}(\mathrm{I})-[\mathrm{GSH}]_{2}$ complex preincubated with Tempol during $90 \mathrm{~min}$, or a preformed Cu(II)-GSSG complex. Results were estimated using a molar absorption coefficient of $6.22 \mathrm{mM}^{-1} \mathrm{~cm}^{-1}$ for NADPH [23] and expressed as micromolar concentration. As such, they represent the sum of free GSSG plus the GSSG released by the addition of EDTA to a $\mathrm{Cu}(\mathrm{II})-\mathrm{GSSG}$ complex present in the assay media.

2.6. Determination of Cuprous Ions. $\mathrm{Cu}(\mathrm{I})$ was assessed as previously described [24], using bathocuproine as $\mathrm{Cu}(\mathrm{I})$ chelating agent. The increase in $\mathrm{OD}_{480 \mathrm{~nm}}$ associated the $\mathrm{Cu}(\mathrm{I})-[\mathrm{BCS}]_{2}$ complex formation which was monitored at $30^{\circ} \mathrm{C}$. The assay was initiated by the addition of BCS $(500 \mu \mathrm{M})$ to samples containing a $\mathrm{Cu}(\mathrm{I})-[\mathrm{GSH}]_{2}$ complex that had been preincubated (during 0-60 min) in the presence or in the absence of Tempol. Results were estimated using a molar absorption coefficient of $12.25 \mathrm{mM}^{-1} \mathrm{~cm}^{-1}$ [24], and expressed as micromolar concentrations of $\mathrm{Cu}(\mathrm{I})$ bathocuproine.

2.7. Determination of Thiol-Titratable Groups and $\mathrm{Cu}(\mathrm{I})$ in a Mixture of $\mathrm{Cu}(\mathrm{I})-[\mathrm{GSH}]_{2}$ plus Hypoxanthine/Xanthine Oxidase. A $\mathrm{Cu}(\mathrm{I})-[\mathrm{GSH}]_{2}$ complex was incubated with a mixture of hypoxanthine (HX; $0.2 \mathrm{mM})$ plus xanthine oxidase $(\mathrm{XO} ; 2 \mathrm{U} / \mathrm{mL})$ during $1-60 \mathrm{~min}\left(30^{\circ} \mathrm{C}\right)$. Since $\mathrm{XO}$ was found to significantly contribute with its own thiols to the TTG assay, its removal was necessary. Thus, mixtures containing the enzyme were centrifuged $(4000 \times \mathrm{g}$, $4^{\circ} \mathrm{C}$ for $40 \mathrm{~min}$ ) through Ultrafree-CL tubes (Centrifugal Filter Devices; NMWL 100000, Millipore). Ultrafiltrates thus 
obtained were subjected to the above-referred TTG, EDTAreleasable GSSG and $\mathrm{Cu}(\mathrm{I})$ assays.

2.8. Data Expression and Analysis. Data points represent the means of at least 3 independently run experiments, each conducted in triplicate. For the sake of simplicity and since the standard deviation values represented less than $5 \%$ of the means, these were omitted from all point graphs (i.e., Figures 1, 2, 4, and 6). In the case of Figures 3, 5, and 7 (plotted as bar graphs), however, since some of the means exhibited standard deviations greater than 5\%, the latter were included. When evaluated, the statistical significance of the difference between bars was assessed using the Student's $t$ test. GraphPad Prism 4 was used as statistical software.

\section{Results and Discussion}

Previous studies indicate that the interaction between GSH and $\mathrm{Cu}^{2+}$ ions leads to the swift formation of a $1: 2$ copperglutathione complex, presumably $\mathrm{Cu}(\mathrm{I})-[\mathrm{GSH}]_{2}$ (as shown in $(\mathrm{Rx} .1))[8,10,25]$. In accordance with such proposed stoichiometry, a near $20 \mu \mathrm{M}$ concentration of thiol-titratable groups (TTG) can be recovered in a solution containing a freshly prepared $10 \mu \mathrm{M}$ concentration of the $\mathrm{Cu}(\mathrm{I})-[\mathrm{GSH}]_{2}$ complex (Figure 1). However, as shown in the same figure, the stability of the thiols can be significantly affected by the sole incubation of such solution at $30^{\circ} \mathrm{C}$. In fact, the level of TTG started to decline steadily along time, to reach after $60 \mathrm{~min}$ one third of the initial values (near $7 \mu \mathrm{M}$ ). Such decline was markedly increased when the solution containing the $\mathrm{Cu}(\mathrm{I})-[\mathrm{GSH}]_{2}$ complex was coincubated at $30^{\circ} \mathrm{C}$ but in the presence of Tempol $(8 \mu \mathrm{M})$. In fact, TTG levels decreased by $75 \%$ to reach a $5 \mu \mathrm{M}$ concentration after $15 \mathrm{~min}$ and totally disappeared after $30 \mathrm{~min}$ of incubation. Since Tempol has no oxidizing effect on GSH molecules (not shown), its TTG-declining effect would be attributable to its superoxide dismutase-mimetic properties [26, 27]. A similar but clearly more accelerated TTG-declining effect of Tempol was observed when the $\mathrm{Cu}(\mathrm{I})-[\mathrm{GSH}]_{2}$ complex and Tempol were coincubated at $37^{\circ} \mathrm{C}$ instead of $30^{\circ} \mathrm{C}$ (insert to Figure 1). Under such conditions, the concentration of thioltitratable groups was negligible already after $10 \mathrm{~min}$. From the figure, it is evident, however, that the sole incubation at $37^{\circ} \mathrm{C}$ itself has a significant TTG-declining effect. Such "Tempol-like effect" of the temperature could be explained by the recently reported temperature-dependent increment in the rate at which the superoxide radicals generated by the complex (Rx. 2) undergo spontaneous dismutation [16, 28].

To assess whether the loss of TTG induced by Tempol arises from the oxidation of the GSH molecules bound to $\mathrm{Cu}(\mathrm{I})$ (within the complex), GSSG was quantified in samples of the above-referred Tempol-treated complex using the GSSG specific NADPH/glutathione reductase assay [22]. To imply that the $20 \mu \mathrm{M}$ loss of TTG observed in Figure 1 arises solely from the oxidation of $\mathrm{Cu}(\mathrm{I})$-bound GSH molecules, an increment of $10 \mu \mathrm{M}$ in the concentration of GSSG would be expected. We found, however, that after incubating the complex with Tempol during $30 \mathrm{~min}\left(\right.$ at $30^{\circ} \mathrm{C}$ ), the concentration of GSSG assayable in the media was only

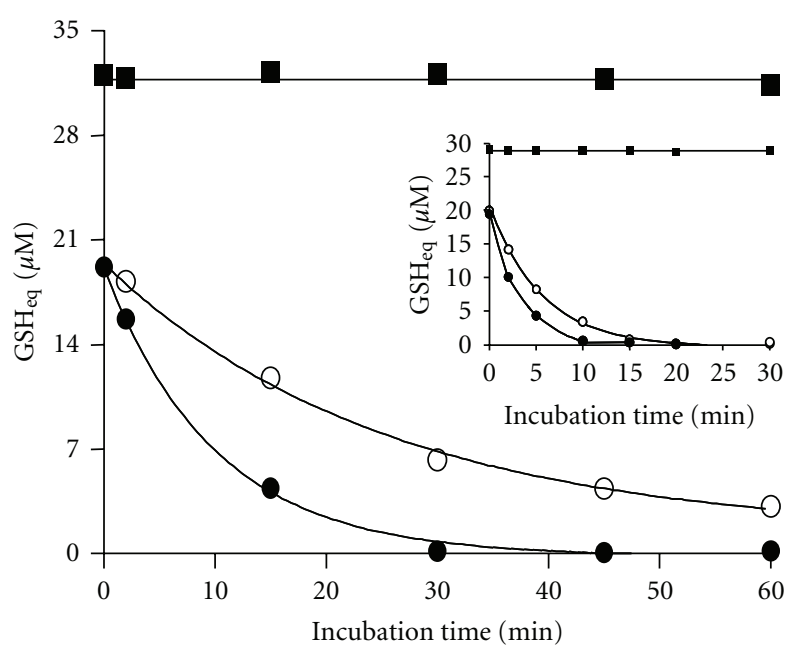

FIGURE 1: Effect of Tempol on thiol-titratable groups of the $\mathrm{Cu}(\mathrm{I})$ $[\mathrm{GSH}]_{2}$ complex. Tempol was added to a solution containing the $\mathrm{Cu}(\mathrm{I})-[\mathrm{GSH}]_{2}$ complex and the mixture incubated at $30^{\circ} \mathrm{C}$ for 0-60 min. Samples from such incubation were added DTNB $(24 \mu \mathrm{M})$ and the increase in $\mathrm{OD}_{412 \mathrm{~nm}}$ registered $5 \mathrm{~min}$ later. Results are expressed as GSH equivalents $(\mu \mathrm{M})$. The symbols represent: (ם) GSH $(30 \mu \mathrm{M}) ;(\bigcirc) \mathrm{Cu}(\mathrm{I})-[\mathrm{GSH}]_{2}(10 \mu \mathrm{M}) ;(\bullet) \mathrm{Cu}(\mathrm{I})-[\mathrm{GSH}]_{2}$ $(10 \mu \mathrm{M})$ plus Tempol $(8 \mu \mathrm{M})$. Insert to the figure shows results obtained from carrying out the same experiment but at $37^{\circ} \mathrm{C}$, during 0-30 $\mathrm{min}$.

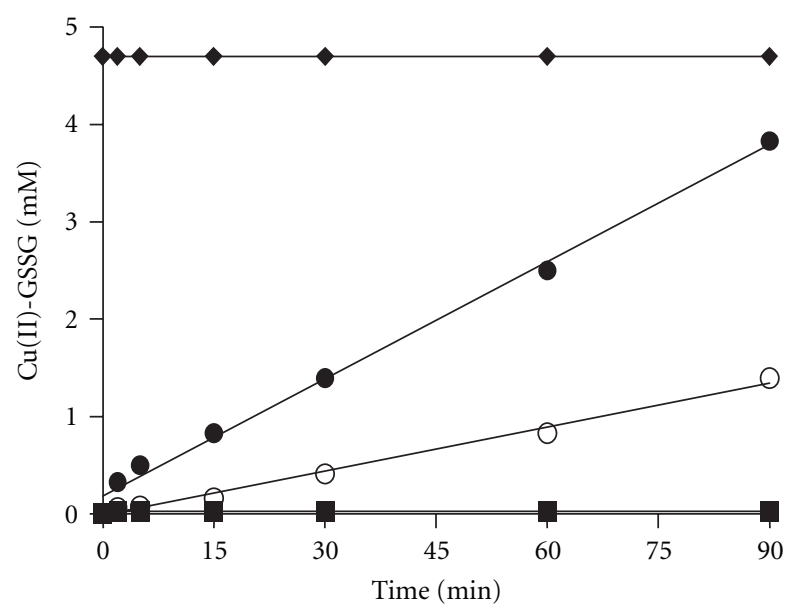

FIGURE 2: Time-dependent formation of $\mathrm{Cu}(\mathrm{II})$-GSSG after the addition of Tempol to a $\mathrm{Cu}(\mathrm{I})-[\mathrm{GSH}]_{2}$ complex. Tempol was added to a solution containing the $\mathrm{Cu}(\mathrm{I})-[\mathrm{GSH}]_{2}$ complex and the mixture incubated at $37^{\circ} \mathrm{C}$ for $0-90 \mathrm{~min}$. Samples were taken during the incubation and the increase in $\mathrm{OD}_{625 \mathrm{~nm}}$ registered. Results are expressed as mM Cu(II)-GSSG concentration. The symbols represent: $(\checkmark) \mathrm{Cu}(\mathrm{II})-\mathrm{GSSG}(5 \mathrm{mM})$; (ם) GSH $(15 \mathrm{mM})$; (O) $\mathrm{Cu}(\mathrm{I})-[\mathrm{GSH}]_{2}(5 \mathrm{mM}) ;(\bullet) \mathrm{Cu}(\mathrm{I})-[\mathrm{GSH}]_{2}(5 \mathrm{mM})$ plus Tempol $(4 \mathrm{mM})$.

$5 \mu \mathrm{M}$ (not shown). Notably, such concentration was already present at time zero, when solutions containing the freshly prepared complex were incubated in the absence or presence of Tempol. Thus, the "limited recovery" of GSSG, namely, only $5 \mu \mathrm{M}$ (instead of the sum of the initial $5 \mu \mathrm{M}$ plus the expected $10 \mu \mathrm{M}$ increment in GSSG) suggests that the actual 


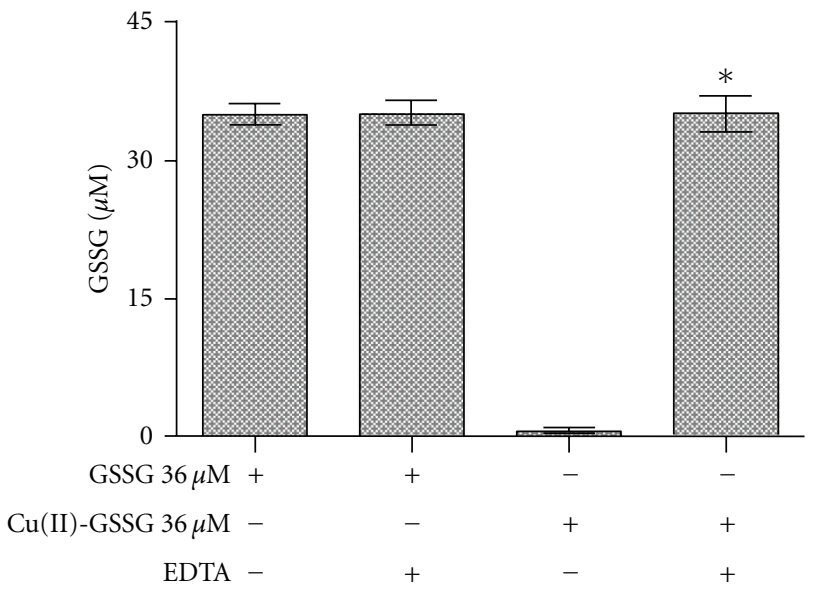

Figure 3: Effect of EDTA on the recovery of GSSG from the Cu(II)GSSG complex assayed by the NADPH/glutathione reductase assay. NADPH $(0.2 \mathrm{mM})$, glutathione reductase $(2 \mathrm{U} / \mathrm{mL})$, and EDTA $(2 \mathrm{mM})$ were added to a solution containing GSSG $(36 \mu \mathrm{M})$ or a preformed $\mathrm{Cu}(\mathrm{II})-\mathrm{GSSG}$ complex $(36 \mu \mathrm{M})$. The decrease in $\mathrm{OD}_{340 \mathrm{~nm}}$ was registered and the results expressed as $\mu \mathrm{M}$ GSSG concentration. The asterisk on the bars indicate that such values are statistically different, at the level of a $P<0.001$, from all other values.

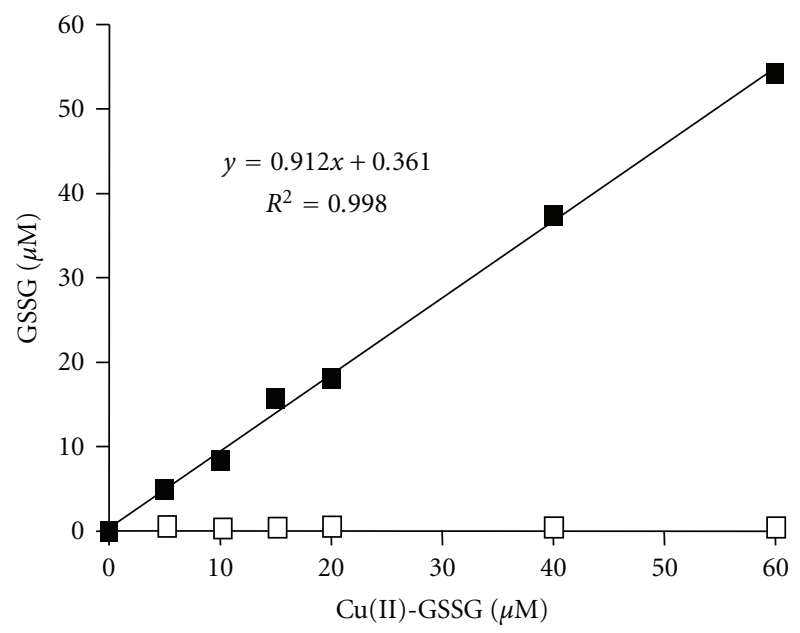

FIgUre 4: Assessment of GSSG by the EDTA-modified NADPH/glutathione reductase assay: correlation between GSSG and $\mathrm{Cu}$ (II)GSSG. NADPH $(0.2 \mathrm{mM})$, glutathione reductase $(2 \mathrm{U} / \mathrm{mL})$, and EDTA $(2 \mathrm{mM})$ were added to solutions containing increasing concentrations of the Cu(II)-GSSG complex $(5-60 \mu \mathrm{M})$. Results are expressed as $\mu \mathrm{M}$ GSSG concentration. The symbols represent: solutions containing the $\mathrm{Cu}$ (II)-GSSG complex $(5-60 \mu \mathrm{M})$ assayed in the presence $(\boldsymbol{\square})$ or in the absence of EDTA $(\square)$.

loss of TTG involves the generation of GSSG molecules that cannot be directly quantified by the NADPH/Glutathione reductase assay.

Recently, using EPR and NMR techniques, we observed that incubation of $\mathrm{Cu}(\mathrm{I})-[\mathrm{GSH}]_{2}$ with SOD leads to the total disappearance of such complex and to a concomitant accumulation of a new complex which was identified as

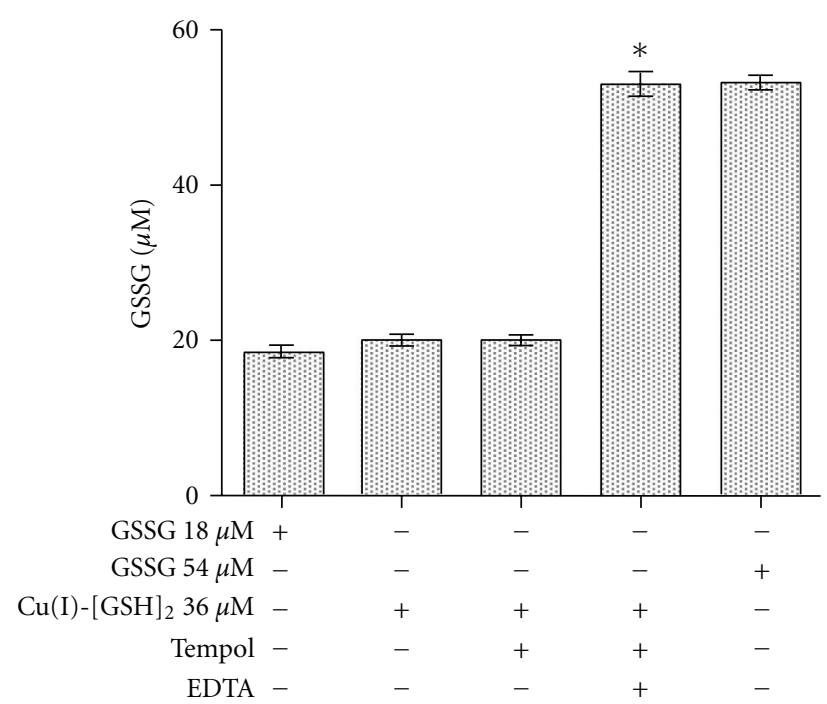

FIGURE 5: Recovery of GSSG from a Tempol-treated Cu(I)-[GSH $]_{2}$ complex using the EDTA-modified NADPH/glutathione reductase assay. GSSG was assessed applying the NADPH/glutathione reductase assay to solutions containing pure GSSG (18 or $54 \mu \mathrm{M})$, the $\mathrm{Cu}(\mathrm{I})-[\mathrm{GSH}]_{2}$ complex $(36 \mu \mathrm{M})$ or a Tempol-treated $\mathrm{Cu}(\mathrm{I})-[\mathrm{GSH}]_{2}$ complex $(36 \mu \mathrm{M})$. The assays were run both in the presence or in the absence of EDTA ( $2 \mathrm{mM})$. Results are expressed as $\mu \mathrm{M}$ GSSG concentration. The asterisk on the bars indicates that such values are statistically different, at the level of a $P<0.001$, from all other values.

$\mathrm{Cu}$ (II)-GSSG [16]. Thus the above-referred only partial recovery of TTG in the form of GSSG from the Tempoltreated $\mathrm{Cu}(\mathrm{I})-[\mathrm{GSH}]_{2}$ complex could be explained by the assumption that all the newly formed GSSG molecules end up bound to $\mathrm{Cu}(\mathrm{II})$ ions. In such form, GSSG molecules would be precluded from being directly quantified by the NADPH/Glutathione reductase assay. In view of the latter consideration, we took advantage of the early reported ability of the $\mathrm{Cu}(\mathrm{II})$-GSSG complex to absorb at $625 \mathrm{~nm}$ [17]. As shown in Figure 2, the incubation of $\mathrm{Cu}(\mathrm{I})-[\mathrm{GSH}]_{2}$ $(5 \mathrm{mM})$ with Tempol (at $37^{\circ} \mathrm{C}$ ) led to a time-dependent, sustained, and linear formation of $\mathrm{Cu}(\mathrm{II})$-GSSG. After 90 min, near $80 \%$ of the initial concentration of $\mathrm{Cu}(\mathrm{I})$ $[\mathrm{GSH}]_{2}$ was converted into $\mathrm{Cu}(\mathrm{II})-\mathrm{GSSG}$. Likewise seen in the experiments depicted in the insert to Figure 1, in which TTG were assessed, we observed that the sole incubation of $\mathrm{Cu}(\mathrm{I})-[\mathrm{GSH}]_{2}$ at $37^{\circ} \mathrm{C}$ led, after $90 \mathrm{~min}$, to its oxidation by near $30 \%$ (Figure 2). Thus, conditions which accelerate the dismutation of the superoxide anions generated in (Rx. 2) (whether Tempol-mediated or temperature-induced) appear to favor the irreversible conversion of $\mathrm{Cu}(\mathrm{I})-[\mathrm{GSH}]_{2}$ into $\mathrm{Cu}(\mathrm{II})-\mathrm{GSSG}((\mathrm{Rx} .2)$ and (Rx. 3))

$$
\mathrm{IOC}+2 \mathrm{O}_{2} \cdot-\underset{T^{\circ}}{\stackrel{\text { Tempol }}{\longrightarrow}} \mathrm{Cu}(\mathrm{II})-\mathrm{GSSG}+\mathrm{H}_{2} \mathrm{O}_{2}+\mathrm{O}_{2}
$$

Although measuring the $\mathrm{OD}$ at $625 \mathrm{~nm}$ seems to be useful to assess the occurrence and formation of $\mathrm{Cu}(\mathrm{II})$-GSSG, its application is limited to the estimation of only millimolar concentrations of such complex $\left(\varepsilon=60 \mathrm{M}^{-1} \mathrm{~cm}^{-1}\right)$ [17]. Thus, in order to assess the oxidative (Tempol-mediated) 


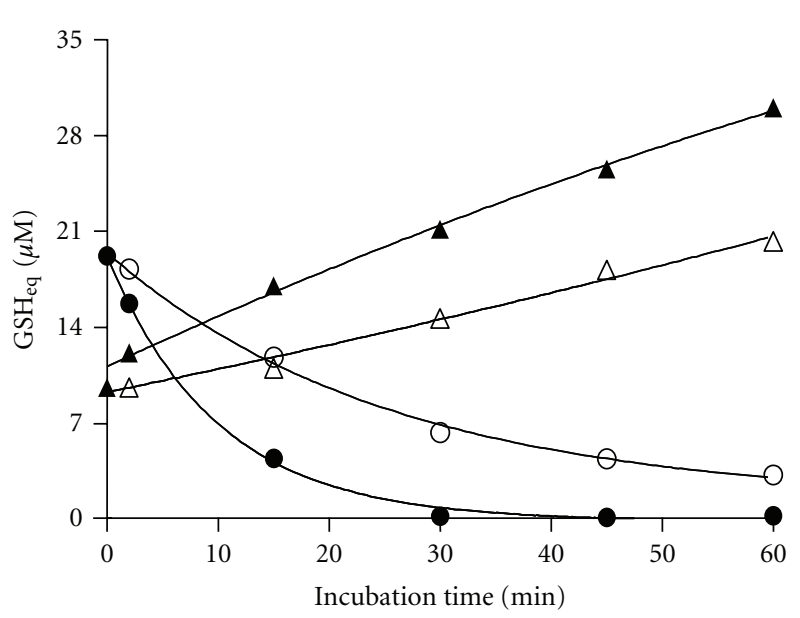

(a)

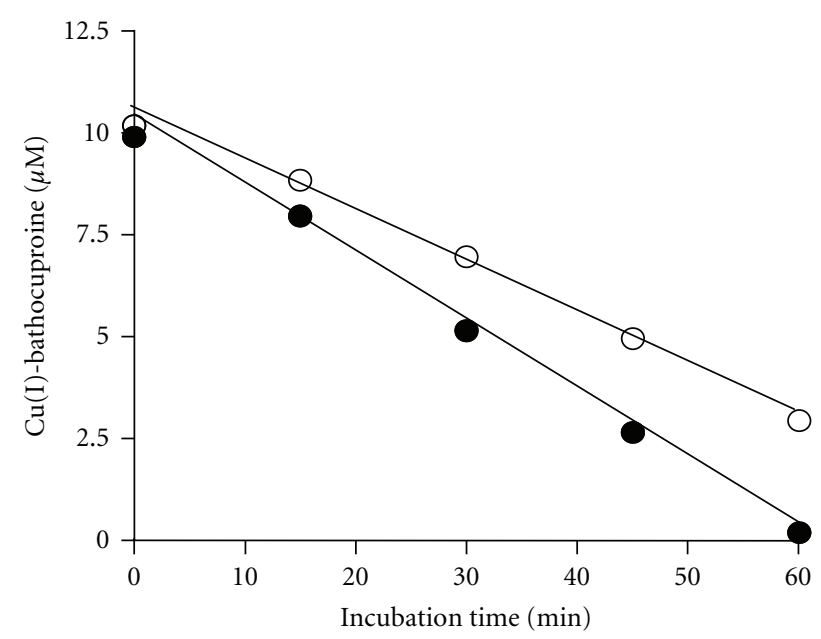

(b)

FIGURE 6: (a) Changes in the thiol-titratable groups and EDTA-releasable GSSG during the exposure of a Cu(I)-[GSH $]_{2}$ complex to Tempol. For the determination of TTG (circles), a mixture of DTNB $(24 \mu \mathrm{M})$ plus EDTA $(2 \mathrm{mM})$, and for that of GSSG (triangles), a mixture of NADPH $(0.2 \mathrm{mM})$ plus glutathione reductase $(2 \mathrm{U} / \mathrm{mL})$ and EDTA $(2 \mathrm{mM})$ were added to samples obtained from the incubation $(0-60 \mathrm{~min}$ at $\left.30^{\circ} \mathrm{C}\right)$ of the $\mathrm{Cu}(\mathrm{I})-[\mathrm{GSH}]_{2}$ complex $(10 \mu \mathrm{M})$ both in the presence (closed symbols) or in the absence (open symbols) of Tempol $(8 \mu \mathrm{M})$. Results are expressed as GSH equivalents $(\mu \mathrm{M})$. (b) Changes in copper (I) during the exposure of a Cu(I)- $[\mathrm{GSH}]_{2}$ complex to Tempol. For the determination of $\mathrm{Cu}(\mathrm{I})$ (circles), bathocuproine $(500 \mu \mathrm{M})$ was added to samples obtained from the incubation $\left(0-60 \mathrm{~min}\right.$, at $\left.30^{\circ} \mathrm{C}\right)$ of the $\mathrm{Cu}(\mathrm{I})-[\mathrm{GSH}]_{2}$ complex $(10 \mu \mathrm{M})$ both in the presence (closed symbols) or in the absence (open symbols) of Tempol $(8 \mu \mathrm{M})$. Cu(I) was assayed at $\mathrm{OD}_{480 \mathrm{~nm}}$ and the results expressed as $\mathrm{Cu}(\mathrm{I})$-bathocuproine $(\mu \mathrm{M})$.

conversion of micromolar concentrations (expected to occur in biological systems) of $\mathrm{Cu}(\mathrm{I})-[\mathrm{GSH}]_{2}$ into $\mathrm{Cu}(\mathrm{II})-\mathrm{GSSG}$, we conducted experiments aimed to quantify those GSSG molecules that are bound to $\mathrm{Cu}(\mathrm{II})$. As already suggested, such molecules do not appear to be quantifiable by the $\mathrm{NADPH} /$ glutathione reductase assay. Figure 3 shows the levels of GSSG obtained upon applying such assay to samples of both free GSSG molecules and a preformed Cu(II)-GSSG complex. As shown, virtually no GSSG molecules (less than $1 \%$ ) were recovered in the samples containing $\mathrm{Cu}(\mathrm{II})$-GSSG $(36 \mu \mathrm{M})$. The latter was, however, totally reversed when the $\mathrm{NADPH} /$ glutathione reductase assay was performed in the presence of EDTA. In fact, under such assay conditions, a $100 \%$ of the GSSG contained in the Cu(II)-GSSG complex was recovered (Figure 3). As such, EDTA did not affect GSSG recovery from a solution containing solely the free disulfide. Thus, the full recovery of GSSG from a solution containing $\mathrm{Cu}(\mathrm{II})$-GSSG suggests that EDTA makes GSSG molecules freely available to react with the reductase. Both EDTA [29] and GSSG [30] are able to chelate $\mathrm{Cu}(\mathrm{II})$. The stability constant of $\mathrm{Cu}(\mathrm{II})$-EDTA $\left(K=6.3 \times 10^{18}\right)$ [29] is, however, five orders of magnitude higher than that of $\mathrm{Cu}(\mathrm{II})$-GSSG $\left(K=5.6 \times 10^{13}\right)$ [30]. Thus, in the presence of EDTA, $\mathrm{Cu}(\mathrm{II})$ ions are most likely to be efficiently removed from $\mathrm{Cu}$ (II)-GSSG. As shown in Figure 4, applying the NADPH/glutathione reductase plus EDTA assay to various concentrations of a preformed $\mathrm{Cu}(\mathrm{II})$-GSSG complex allowed the indirect and total quantification of the complex. Linearity for such assay conditions was established within the 5-60 $\mu \mathrm{M}$ range of concentrations (Figure 4).
Taking advantage of the ability of EDTA to release the GSSG bound to $\mathrm{Cu}(\mathrm{II})$, the formation of $\mathrm{Cu}(\mathrm{II})$-GSSG in a Tempol-treated $\mathrm{Cu}(\mathrm{I})-[\mathrm{GSH}]_{2}$ solution was quantitatively re-assessed. To distinguish between free and $\mathrm{Cu}(\mathrm{II})$-bound GSSG molecules, the levels of the disulfide were assessed both in the absence and in the presence of EDTA in the assay media, respectively (Figure 5). When a $36 \mu \mathrm{M} \mathrm{Cu}(\mathrm{I})-[\mathrm{GSH}]_{2}$ solution (prepared by mixing $36 \mu \mathrm{M}$ of $\mathrm{Cu}^{2+}$ plus $108 \mu \mathrm{M}$ of GSH) was assayed in the absence of EDTA, an $18 \mu \mathrm{M}$ concentration of GSSG was recovered as free disulfide. Such concentration fully corresponds to that expected to occur if, as in (Rx. 1), GSH oxidation had arisen exclusively from the initial reduction of the $\mathrm{Cu}^{2+}$ ions needed to form the $\mathrm{Cu}(\mathrm{I})$ $[\mathrm{GSH}]_{2}$ complex. An identical result was found when GSSG was assayed, also in the absence of EDTA, in a Tempol-treated $\mathrm{Cu}(\mathrm{I})-[\mathrm{GSH}]_{2}$ solution (Figure 5$)$. In turn, when the latter solution was assayed in the presence of EDTA, the total concentration of GSSG recovered raised from $18 \mu \mathrm{M}$ to $54 \mu \mathrm{M}$. The latter value corresponds exactly to the sum of $18 \mu \mathrm{M}$ (occurring as free GSSG) plus $36 \mu \mathrm{M}$ (of GSSG released by EDTA from the $\mathrm{Cu}$ (II)-GSSG complex). According to these results, it would be possible to estimate the concentration of GSSG bound to $\mathrm{Cu}(\mathrm{II})$, namely, that of the $\mathrm{Cu}(\mathrm{II})$-GSSG complex, by subtracting the concentration of GSSG assayed in the absence from that estimated in the presence of EDTA. Figure 6(a) shows the results from applying this EDTAdependent GSSG recovery assay to $\mathrm{Cu}(\mathrm{I})$ - $[\mathrm{GSH}]_{2}$-containing solution incubated in the absence or in the presence of Tempol. While the descending curves of Figure 6(a) depict the loss of TTG that affect the complex along its $60 \mathrm{~min}$ of incubation (data from Figure 1), the ascending ones show 


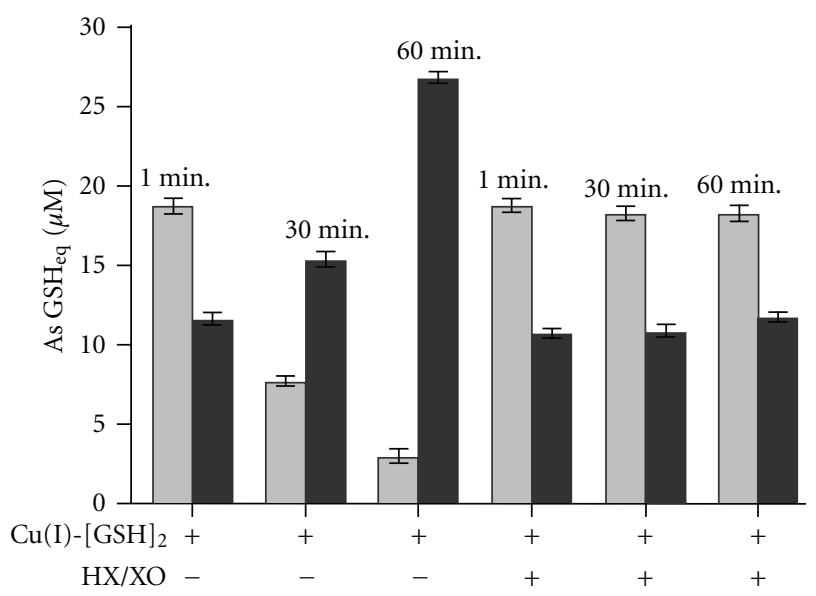

(a)

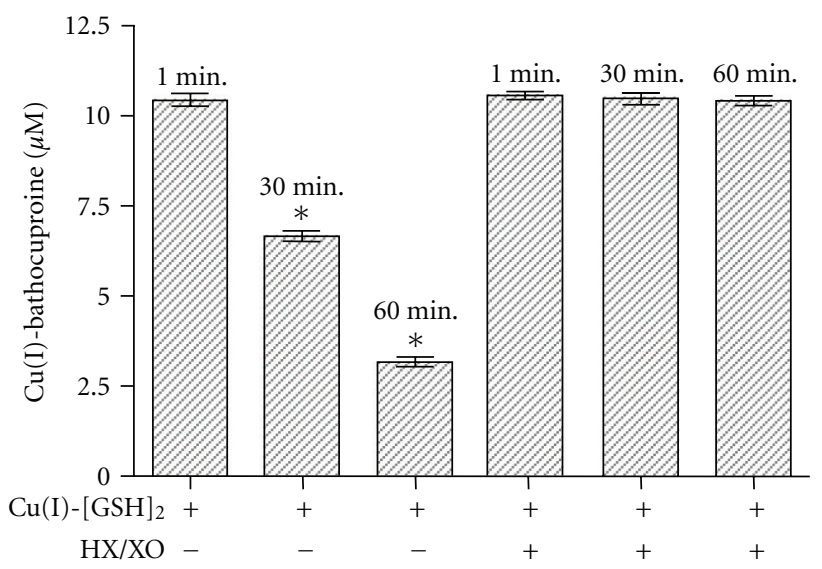

(b)

FIGURE 7: (a) Effect of the exposure of $\mathrm{Cu}(\mathrm{I})-[\mathrm{GSH}]_{2}$ to an exogenous source of superoxide radicals on the thiol-titratable groups and EDTA-releasable GSSG. Hypoxanthine $(0.2 \mathrm{mM})$ plus xanthine oxidase $(\mathrm{XO} ; 2 \mathrm{U} / \mathrm{mL})$ were added to a solution containing the $\mathrm{Cu}(\mathrm{I})$ $[\mathrm{GSH}]_{2}$ complex $(10 \mu \mathrm{M})$, and the mixture was incubated for $0-60 \mathrm{~min}$, at $30^{\circ} \mathrm{C}$. Samples were taken from the incubation media after 1 , 30, and $60 \mathrm{~min}$ and analyzed for their TTG (light grey bar) and EDTA-releasable GSSG (dark grey bar) levels. Results are expressed as GSH equivalents $(\mu \mathrm{M})$. (b) Effect of the exposure of $\mathrm{Cu}(\mathrm{I})-[\mathrm{GSH}]_{2}$ to an exogenous source of superoxide radicals on the concentration of copper (I). Hypoxanthine $(0.2 \mathrm{mM})$ plus xanthine oxidase $(\mathrm{XO} ; 2 \mathrm{U} / \mathrm{mL})$ were added to a solution containing the $\mathrm{Cu}(\mathrm{I})-[\mathrm{GSH}]_{2}$ complex $(10 \mu \mathrm{M})$ and the mixture was incubated for $0-60 \mathrm{~min}$, at $30^{\circ} \mathrm{C}$. Samples were taken from the incubation media after 1, 30, and $60 \mathrm{~min}$ and analyzed for their $\mathrm{Cu}(\mathrm{I})$ concentration. Results are expressed as $\mathrm{Cu}(\mathrm{I})$-bathocuproine $(\mu \mathrm{M})$. The asterisk on the bars indicate that such values are statistically different, at the level of a $P<0.001$, from all other values.

the corresponding increments in the EDTA-releasable GSSG. In both cases, results are expressed as GSH equivalents for comparative purposes. Interestingly, regardless of whether Tempol was added to the complex, the loss of TTG was along time accompanied by a concomitant but only quantitativelypartial gain of EDTA-releasable GSSG (Figure 6(a)). For instance, in the case of the Tempol-treated solution, the complex underwent after $30 \mathrm{~min}$ a total loss of its TTG, decreasing from $20 \mu \mathrm{M}$ to $0 \mu \mathrm{M}$ GSH eq. In turn, the gain in GSSG was only half of such loss, as manifested by an increase in GSH eq. from $10 \mu \mathrm{M}$ to $20 \mu \mathrm{M}$. Thus, after $30 \mathrm{~min}$, only $50 \%$ of the TTG that had disappeared could be accounted for by the formation of EDTA-releasable GSSG. Comparatively, after $60 \mathrm{~min}$ of incubation, the loss of GSH was totally accounted for by the estimated increment in GSSG. In fact, the concentration of GSSG raised from $10 \mu \mathrm{M}$ to $30 \mu \mathrm{M}$ GSH eq., leveling the $20 \mu \mathrm{M}$ of GSH eq. that had been lost earlier as TTG. The lack of correspondence between the GSH eq. lost as TTG and those gained as EDTA-releasable GSSG seen after 30 min could be explained assuming that Tempol accelerated oxidative changes in the $\mathrm{Cu}(\mathrm{I})-[\mathrm{GSH}]_{2}$ molecule which lead to the formation of the an "intermediate oxidized complex". Presumably, the structure of such intermediate would feature some form of thiols that are not reactive to DTNB (i.e., not titratable as TTG) or disulfides that are not susceptible to be quantified by the EDTA/NADPH/glutathione reductase assay (different from $\mathrm{Cu}(\mathrm{II})$-bound GSSG molecules). The formation of such intermediate (referred to as IOC in (Rx. 2)) would precede and potentially lead to the formation of the $\mathrm{Cu}$ (II)-GSSG complex.
To further our understanding on the changes involved in the oxidative conversion of $\mathrm{Cu}(\mathrm{I})-[\mathrm{GSH}]_{2}$ into $\mathrm{Cu}(\mathrm{II})-\mathrm{GSSG}$, we investigated whether exposure of the former complex to Tempol involves also time-dependent changes on the copper bound to GSH. As shown in Figure 6(b), Tempol led to a time-dependent decrease in the concentration of $\mathrm{Cu}(\mathrm{I})$, as assessed by the $\mathrm{Cu}(\mathrm{I})$-bathocuproine assay [24] Interestingly, after $30 \mathrm{~min}$ of incubation, almost $50 \%$ of the $\mathrm{Cu}(\mathrm{I})$ still remained as such. The latter is in sharp contrast with the fact that at the indicated time, $100 \%$ of the TTG had already disappeared (data in Figure 6(a)). The lack of correspondence between the magnitude of the oxidative changes that affect $\mathrm{Cu}(\mathrm{I})$ and $\mathrm{GSH}$ within the $\mathrm{Cu}(\mathrm{I})-[\mathrm{GSH}]_{2}$ complex suggests that after $30 \mathrm{~min}$, the $\mathrm{Cu}(\mathrm{I})$ that remains as such would no longer form part of such complex. As for the TTG, the extent of the disappearance of $\mathrm{Cu}(\mathrm{I})$ shown in Figure 6(b) was also accelerated by Tempol. Both changes support the concept that removal of superoxide from (Rx. 2) favors the conversion of the putative intermediate into $\mathrm{Cu}$ (II)-GSSG (Rx. 3) and are in line with data from Figure 2, where Tempol was shown to accelerate the formation of such complex.

Furthermore, when the incubation of $\mathrm{Cu}(\mathrm{I})-[\mathrm{GSH}]_{2}$ plus Tempol was extended to $60 \mathrm{~min}$, time at which $100 \%$ of the $\mathrm{Cu}(\mathrm{I})$ had disappeared (Figure $6(\mathrm{~b})$ ), a 100\% of the TTG that was lost at such time could be recovered as EDTA-releasable GSSG (Figure 6(a)). The latter changes would indicate that after $60 \mathrm{~min}$, removal of superoxide by Tempol secures the total conversion of $\mathrm{Cu}(\mathrm{I})-[\mathrm{GSH}]_{2}$ complex (and its oxidized intermediate) into Cu(II)-GSSG. Interestingly, such conversion also takes place even in the absence of Tempol, 
but at a much slower rate, suggesting that superoxide radicals generated in (Rx. 2) also undergo spontaneous dismutation under such incubation condition $\left(30^{\circ} \mathrm{C}\right)$.

Based on all the above presented results, we propose that removal of superoxide anions from (Rx. 2) (whether spontaneous or Tempol-induced) leads time dependently to the oxidative disappearance of GSH (evidenced through a loss of TTG and formation of EDTA-releasable GSSG) and $\mathrm{Cu}(\mathrm{I})$ from $\mathrm{Cu}(\mathrm{I})-[\mathrm{GSH}]_{2}$. Based on such contention, we pursued additional experiments to investigate the superoxidedependent reversibility of (Rx. 2). Specifically, we evaluated whether increasing the flow of superoxide in such reaction, through an exogenous source of such radicals, could slow the rate at which the $\mathrm{Cu}(\mathrm{I})-[\mathrm{GSH}]_{2}$ complex undergoes the oxidation of $\mathrm{GSH}$ and $\mathrm{Cu}(\mathrm{I})$. Thus, a solution containing $\mathrm{Cu}(\mathrm{I})-[\mathrm{GSH}]_{2}$ was incubated (during 1,30 or $60 \mathrm{~min}$ ) in the absence or in the presence of hypoxanthine plus xanthine oxidase $(\mathrm{HX} / \mathrm{XO})$. Figure $7(\mathrm{a})$ depicts the changes in the TTG and the EDTA-releasable GSSG levels, expressing both changes in terms of GSH equivalents. As seen, the incubation of $\mathrm{Cu}(\mathrm{I})-[\mathrm{GSH}]_{2}$ plus $\mathrm{HX} / \mathrm{XO}$ prevented by near $70 \%$ and by $72 \%$ the loss of TTG observed otherwise at 30 and $60 \mathrm{~min}$, respectively. Regarding the formation of EDTA-releasable GSSG, the presence of HX/XO totally prevented the timedependent increment that the complex underwent in the absence of the additional source of superoxide. Consistent with these results, the HX/XO mixture also totally prevented the time-dependent loss of bathocuproine assayable $\mathrm{Cu}(\mathrm{I})$ ions (Figure 7(b)). Therefore, data from Figures 7(a) and 7 (b) support the concept that (Rx. 2) is indeed reversible and suggest that preventing the removal of the superoxide anions generated in such reaction is key to maintain its equilibrium and to secure that in the same reaction, the postulated IOC, instead of shifting towards the formation of the $\mathrm{Cu}$ (II)-GSSG complex (Rx. 3), would serve primarily to regenerate the $\mathrm{Cu}(\mathrm{I})-[\mathrm{GSH}]_{2}$ complex (Rx. 2). Most cells contain significant amounts of SOD and a number of other molecules susceptible to react with superoxide, like GSH and ascorbate which could reach millimolar concentrations within the cells. In addition to the latter superoxide-reacting molecules, ferritin, the major intracellularly occurring ironstoring protein was recently reported to react with the superoxide anions generated by the $\mathrm{Cu}(\mathrm{I})-[\mathrm{GSH}]_{2}$ complex [31]. Thus, it could be speculated that due to the presence of various superoxide removing or reacting molecules, the $\mathrm{Cu}(\mathrm{I})-[\mathrm{GSH}]_{2}$ complex might occur within cells, not only as such but also as $\mathrm{Cu}(\mathrm{II})-\mathrm{GSSG}$, its end-oxidation product.

\section{Conclusions}

Removal of superoxide anions from a solution containing the $\mathrm{Cu}(\mathrm{I})-[\mathrm{GSH}]_{2}$ complex led to losses in GSH molecules that were of greater magnitude than those affecting the $\mathrm{Cu}(\mathrm{I})$ metal. Since the loss of TTG was only partially accounted for by the amount of $\mathrm{Cu}(\mathrm{II})$-GSSG molecules accumulated, the formation of an "intermediate oxidized complex", whose thiols are neither reactive towards DTNB nor susceptible to be quantified by the EDTA/NADPH/glutathione reductase assay, can be postulated. Since the oxidative drops in GSH and $\mathrm{Cu}(\mathrm{I})$ were totally prevented by the exposure of the $\mathrm{Cu}(\mathrm{I})-[\mathrm{GSH}]_{2}$ complex to an external source of superoxide, it is suggested that the generation of superoxide in ( $\mathrm{Rx} .2)$ would imply an obliged formation of the above-referred intermediate. Results support the contention that the subsequent oxidation of such intermediate into $\mathrm{Cu}$ (II)-GSSG or its reduction back into $\mathrm{Cu}(\mathrm{I})-[\mathrm{GSH}]_{2}$ can be favoured by either the removal or the addition of superoxide anions to the media, respectively.

\section{Acknowledgment}

This work was supported by FONDECYT Grants no. 1110018 and no. 11090115.

\section{References}

[1] J. H. Freedman, M. R. Ciriolo, and J. Peisach, "The role of glutathione in copper metabolism and toxicity," Journal of Biological Chemistry, vol. 264, no. 10, pp. 5598-5605, 1989.

[2] J. H. Freedman and J. Peisach, "Intracellular copper transport in cultured hepatoma cells," Biochemical and Biophysical Research Communications, vol. 164, no. 1, pp. 134-140, 1989.

[3] S. Ferruzza, Y. Sambuy, M. R. Ciriolo et al., "Copper uptake and intracellular distribution in the human intestinal Caco-2 cell line," BioMetals, vol. 13, no. 2, pp. 179-185, 2000.

[4] M. R. Ciriolo, A. Desideri, M. Paci, and G. Rotilio, "Reconstitution of $\mathrm{Cu}, \mathrm{Zn}$-superoxide dismutase by the $\mathrm{Cu}(\mathrm{I})$.glutathione complex," Journal of Biological Chemistry, vol. 265, no. 19, pp. 11030-11034, 1990.

[5] A. M. Da Costa Ferreira, M. R. Ciriolo, L. Marcocci, and G. Rotilio, "Copper(I) transfer into metallothionein mediated by glutathione," Biochemical Journal, vol. 292, no. 3, pp. 673-676, 1993.

[6] O. M. Steinebach and H. T. Wolterbeek, "Role of cytosolic copper, metallothionein and glutathione in copper toxicity in rat hepatoma tissue culture cells," Toxicology, vol. 92, no. 1-3, pp. 75-90, 1994.

[7] G. Musci, S. Di Marco, G. C. Bellenchi, and L. Calabrese, "Reconstitution of ceruloplasmin by the $\mathrm{Cu}(\mathrm{I})$-glutathione complex: evidence for a role of $\mathrm{Mg}^{2+}$ and ATP," Journal of Biological Chemistry, vol. 271, no. 4, pp. 1972-1978, 1996.

[8] R. Osterberg, R. Ligaarden, and D. Persson, "Copper(I) complexes of penicillamine and glutathione," Journal of Inorganic Biochemistry, vol. 10, no. 4, pp. 341-355, 1979.

[9] N. Spear and S. D. Aust, "Effects of glutathione on Fenton reagent-dependent radical production and DNA oxidation," Archives of Biochemistry and Biophysics, vol. 324, no. 1, pp. 111-116, 1995.

[10] A. V. Kachur, C. J. Koch, and J. E. Biaglow, "Mechanism of copper-catalyzed oxidation of glutathione," Free Radical Research, vol. 28, no. 3, pp. 259-269, 1998.

[11] A. Corazza, I. Harvey, and P. J. Sadler, ${ }^{11} \mathrm{H},{ }^{13} \mathrm{C}-\mathrm{NMR}$ and Xray absorption studies of copper(I) glutathione complexes," European Journal of Biochemistry, vol. 236, no. 2, pp. 697-705, 1996.

[12] P. M. Hanna and R. P. Mason, "Direct evidence for inhibition of free radical formation from $\mathrm{Cu}(\mathrm{I})$ and hydrogen peroxide by 
glutathione and other potential ligands using the EPR spintrapping technique," Archives of Biochemistry and Biophysics, vol. 295, no. 1, pp. 205-213, 1992.

[13] L. Milne, P. Nicotera, S. Orrenius, and M. J. Burkitt, "Effects of glutathione and chelating agents on copper-mediated DNA oxidation: pro-oxidant and antioxidant properties of glutathione," Archives of Biochemistry and Biophysics, vol. 304, no. 1, pp. 102-109, 1993.

[14] M. J. Burkitt, "A critical overview of the chemistry of copperdependent low density lipoprotein oxidation: roles of lipid hydroperoxides, $\alpha$-tocopherol, thiols, and ceruloplasmin," Archives of Biochemistry and Biophysics, vol. 394, no. 1, pp. 117-135, 2001.

[15] H. Speisky, M. Gómez, C. Carrasco-Pozo, E. Pastene, C. Lopez-Alarcón, and C. Olea-Azar, "Cu(I)-Glutathione complex: a potential source of superoxide radicals generation," Bioorganic and Medicinal Chemistry, vol. 16, no. 13, pp. 65686574, 2008.

[16] H. Speisky, M. Gómez, F. Burgos-Bravo et al., "Generation of superoxide radicals by copper-glutathione complexes: redoxconsequences associated with their interaction with reduced glutathione," Bioorganic and Medicinal Chemistry, vol. 17, no. 5, pp. 1803-1810, 2009.

[17] W. S. Postal, E. J. Vogel, C. M. Young, and F. T. Greenaway, "The binding of copper(II) and zinc(II) to oxidized glutathione," Journal of Inorganic Biochemistry, vol. 25, no. 1, pp. 25-33, 1985.

[18] G. L. Ellman, “Tissue sulfhydryl groups,” Archives of Biochemistry and Biophysics, vol. 82, no. 1, pp. 70-77, 1959.

[19] I. Rahman, A. Kode, and S. K. Biswas, "Assay for quantitative determination of glutathione and glutathione disulfide levels using enzymatic recycling method," Nature Protocols, vol. 1, no. 6, pp. 3159-3165, 2007.

[20] C. Carrasco-Pozo, M. E. Aliaga, C. Olea-Azar, and H. Speisky, "Double edge redox-implications for the interaction between endogenous thiols and copper ions: in vitro studies," Bioorganic and Medicinal Chemistry, vol. 16, no. 22, pp. 9795-9803, 2008.

[21] P. W. Riddles, R. L. Blakeley, and B. Zerner, "Ellman's reagent: 5,5'-dithiobis(2-nitrobenzoic acid)—a reexamination," Analytical Biochemistry, vol. 94, no. 1, pp. 75-81, 1979.

[22] F. Tietze, "Enzymic method for quantitative determination of nanogram amounts of total and oxidized glutathione: applications to mammalian blood and other tissues," Analytical Biochemistry, vol. 27, no. 3, pp. 502-522, 1969.

[23] E. Jablonski and M. DeLuca, "Purification and properties of the NADH and NADPH specific FMN oxidoreductases from Beneckea harveyi," Biochemistry, vol. 16, no. 13, pp. 29322936, 1977.

[24] J. W. Moffett, R. G. Zika, and R. G. Petasne, "Evaluation of bathocuproine for the spectro-photometric determination of copper(I) in copper redox studies with applications in studies of natural waters," Analytica Chimica Acta, vol. 175, no. C, pp. 171-179, 1985.

[25] B. C. Gilbert, S. Silvester, and P. H. Walton, "Spectroscopic, kinetic and mechanistic studies of the influence of ligand and substrate concentration on the activation by peroxides of CuIthiolate and other CuI complexes," Journal of the Chemical Society. Perkin Transactions 2, no. 6, pp. 1115-1121, 1999.

[26] J. B. Mitchell, W. DeGraff, D. Kaufman et al., "Inhibition of oxygen-dependent radiation-induced damage by the nitroxide superoxide dismutase mimic, tempol," Archives of Biochemistry and Biophysics, vol. 289, no. 1, pp. 62-70, 1991.
[27] B. P. Soule, F. Hyodo, K. I. Matsumoto et al., "The chemistry and biology of nitroxide compounds," Free Radical Biology and Medicine, vol. 42, no. 11, pp. 1632-1650, 2007.

[28] M. E. Aliaga, C. Carrasco-Pozo, C. López-Alarcón, and H. Speisky, "The $\mathrm{Cu}(\mathrm{I})$-glutathione complex: factors affecting its formation and capacity to generate reactive oxygen species," Transition Metal Chemistry, vol. 35, no. 3, pp. 321-329, 2010.

[29] M. S. Brewer and G. L. Baughman, "Experimental estimation of stability constants of copperised azo dyes in water," Dyes and Pigments, vol. 60, no. 3, pp. 243-247, 2004.

[30] V. G. Shtyrlin, Y. I. Zyavkina, V. S. Ilakin, R. R. Garipov, and A. V. Zakharov, "Structure, stability, and ligand exchange of copper(II) complexes with oxidized glutathione," Journal of Inorganic Biochemistry, vol. 99, no. 6, pp. 1335-1346, 2005.

[31] M. E. Aliaga, C. Carrasco-Pozo, C. López-Alarcón, C. Olea-Azar, and H. Speisky, "Superoxide-dependent reduction of free $\mathrm{Fe}^{3+}$ and release of $\mathrm{Fe}^{2+}$ from ferritin by the physiologically-occurring $\mathrm{Cu}(\mathrm{I})$-glutathione complex," Bioorganic and Medicinal Chemistry, vol. 19, no. 1, pp. 534-541, 2011. 


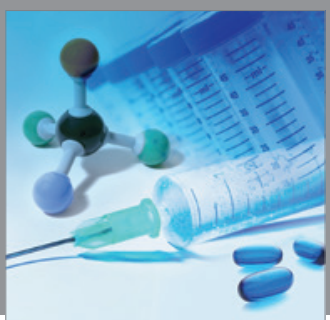

International Journal of

Medicinal Chemistry

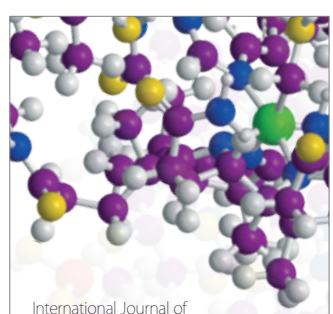

Carbohydrate Chemistry

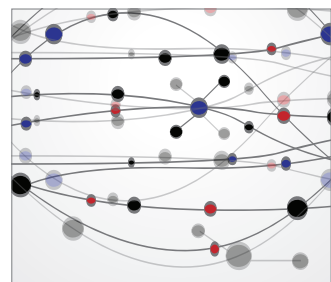

The Scientific World Journal
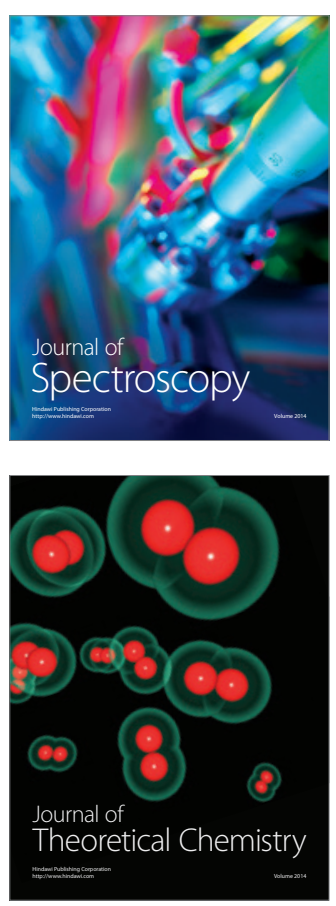
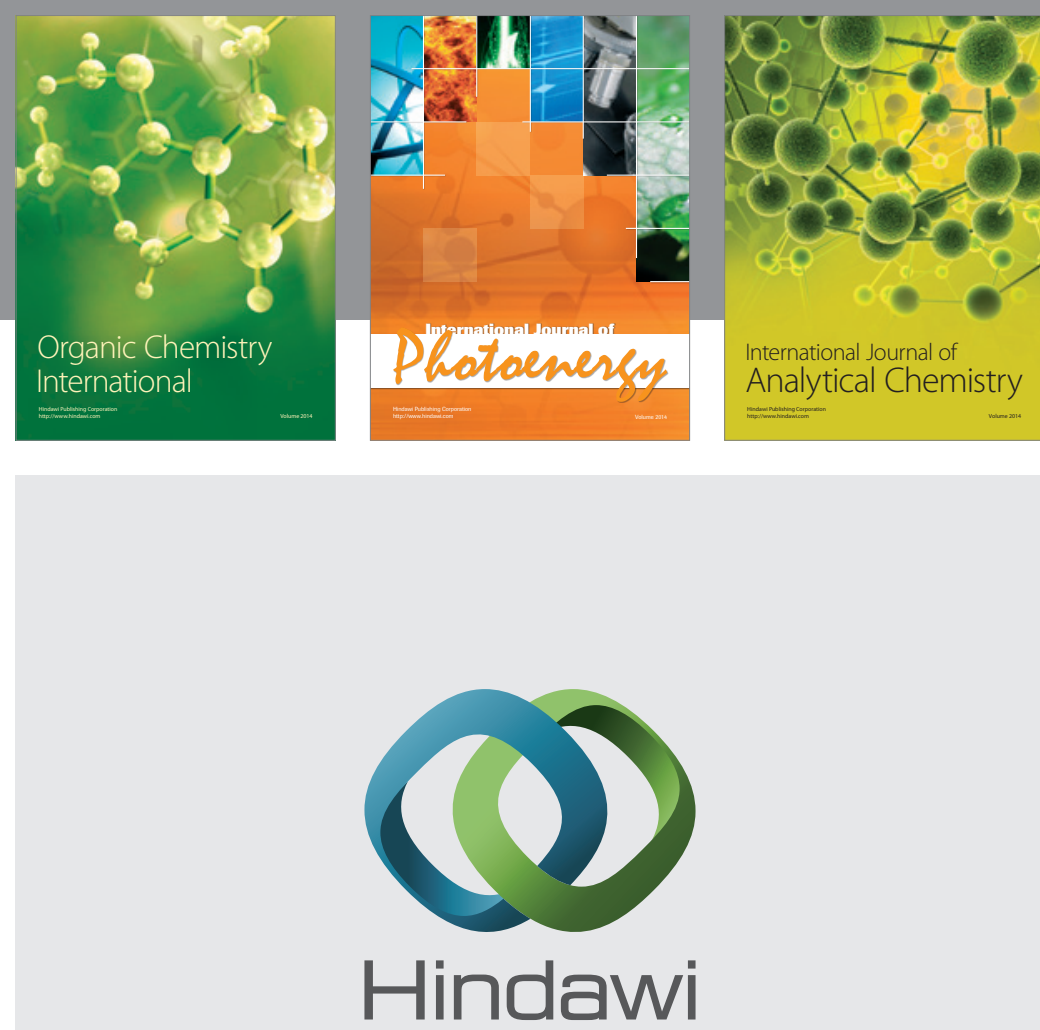

Submit your manuscripts at

http://www.hindawi.com
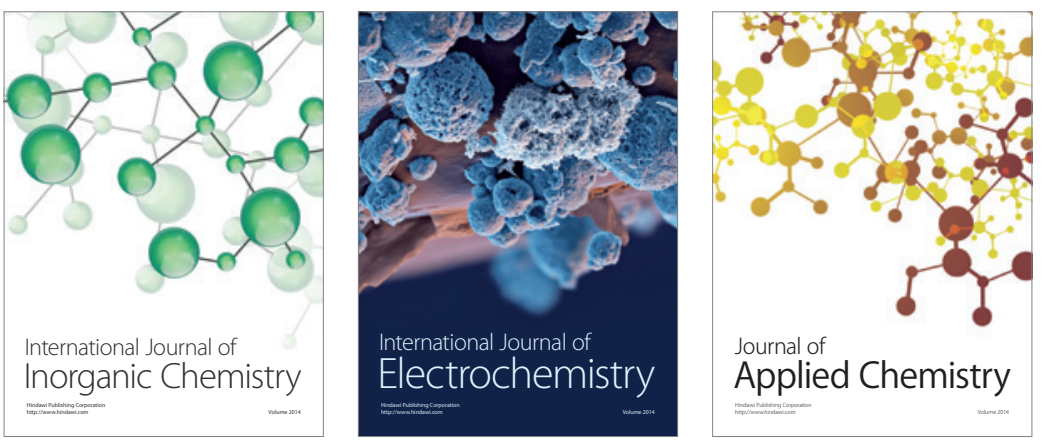

Journal of

Applied Chemistry
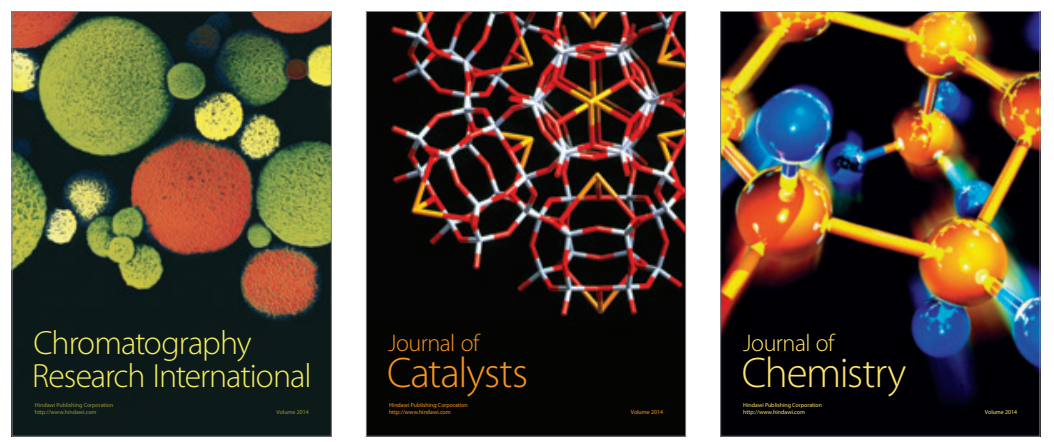
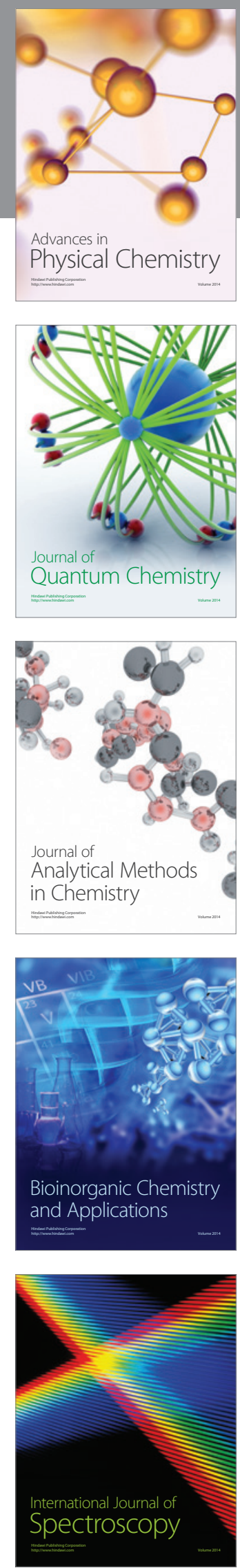